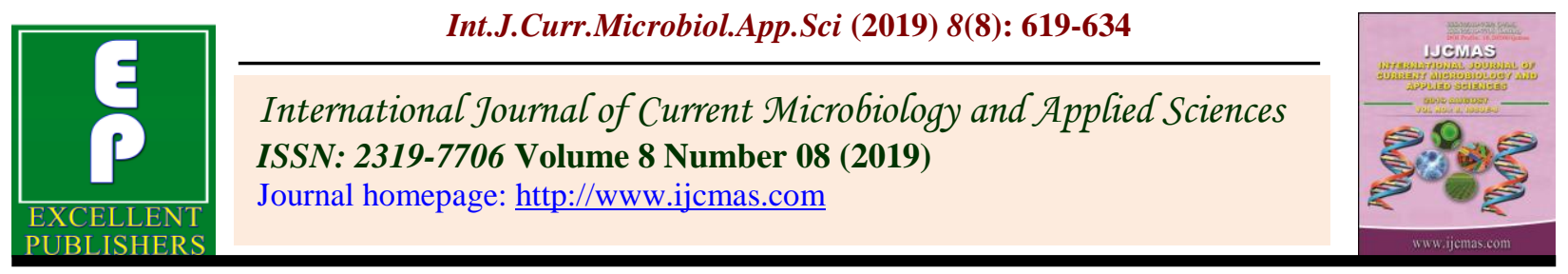

Original Research Article

https://doi.org/10.20546/ijcmas.2019.808.073

\title{
Development and Fabrication of Small Capacity Garlic Peeler
}

\author{
Maninder Kaur*, Preetinder Kaur and Mahesh Kumar \\ Department of Processing and Food Engineering, Punjab Agricultural University, Ludhiana, \\ Punjab, India
}

*Corresponding author

\section{A B S T R A C T}

Keywords

Engineering properties, Garlic peeler,

Pretreatment, Peeling efficiency, Peeled clove recovery

\section{Article Info}

Accepted:

07 July 2019

Available Online:

10 August 2019
Garlic (Allium sativum L.) is one of the most perennial bulb crops of Liliaceae family. It is widely used as a condiment and for medicinal and pharmaceutical preparations. Traditional methods of garlic peeling are laborious, time and cost intensive. The present study was undertaken to develop and evaluate the performance of small capacity garlic peeler so as to overcome the time consumption and cost intensiveness. Engineering properties of garlic relevant to peeler development were identified and measured. It worked on the abrasion principle with very little damage to the cloves after peeling. The peeler was analyzed for its performance at different roller speeds and pretreatment conditions. An evaluation of the performance of the developed peeler with hot air pretreated cloves indicated that it recovered $39.40 \%$ of peeled cloves after peeling at $400 \mathrm{rpm}$ of roller speed. For the control samples, maximum peeled clove recovery was $33.45 \%$. The capacity of the machine was found to be $15 \mathrm{~kg} / \mathrm{h}$. The maximum peeling efficiency observed was $48.13 \%$ with hot air pretreated samples peeled at $400 \mathrm{rpm}$ of roller speed. An economic analysis indicated that the developed garlic peeler could be profitably used for the small scale peeling operations.

\section{Introduction}

Garlic (Allium sativum L.), the spice of human life, is one the most important perennial bulb crops of the lily family (Liliaceae) which is grown all over the plains of India and is used as a condiment throughout the country. India ranks second after China in world's garlic production and contribute $14 \%$ of the world area. According to National Horticulture Database (2011), the total production of spices in India during 2010-2011 was 5351 thousand million tonnes from an area of 2940 thousand hectares giving productivity of $1.8 \mathrm{MT} / \mathrm{ha}$. The share of area under garlic is 200.60 thousand hectare with productivity of 53MT/ha. During the same period, Punjab produced 63.5 thousand million tonnes from an area of 18.4 thousand hectares, giving the productivity of $3.5 \mathrm{MT} / \mathrm{ha}$. Punjab ranks first with the highest yield at 14.73 tonnes / ha.

Fresh garlic is characterized as having a distinct aromatic odour which is seldom 
carried over into processed garlic (Pezutti and Crapsite 1997). The flavour of garlic is attributed to the sulfur containing volatiles. By the action of an enzyme allinase, allyl $-\mathrm{S}$ cysteine sulfoxide (allin) is converted to diallyl thiosulfinates (allicin) and then dispropotinately to disulfides and thiosulfinates.

Garlic is valued for its flavor and has an extensive commercial importance because of its wide medicinal value and application in food and pharmaceutical preparations (Sharma and Prasad, 2001). It has been recognized as a valuable food condiment in everyday cooking. Garlic is commonly processed into dehydrated powder, flakes and slices (Ahmad 1996). This involves a cumbersome unit operation of peeling. With changing lifestyles, people are moving towards readily available processed products. During garlic peeling the thin membrane skin is to be removed off from the segments. Various methods such as lye peeling, hot water blanching, oven peeling, flame peeling etc are used for peeling the garlic. In lye peeling method, garlic is immersed in hot caustic soda solution in the lye peeler itself followed by vigorous water rinse to remove the chemicals adhered to the skin. The cloves are then neutralized in acid bath and trimmed to give perfect finish. Hot water blanching is a traditional method of peeling that involves the submergence of cloves in warm water for 5-10 minutes. The outer skin gets softened and can be easily peeled by hand. In the oven method of peeling, garlic is placed in oven for 5-10 seconds. The root is then cut and skin slides off easily. Flame peeling is another tedious method in which garlic is brought into direct contact with the live flame. High temperature burns the outer skin and can be easily removed.

Commonly available mechanical peeling methods involve the use of abrasion gadgets.
These have been found infeasible as the cloves are crushed during the process (Mudgal et al., 1998). At present, there is need to develop efficient processing and peeling equipments for the garlic cloves. For this, the knowledge of basic engineering and physical properties of garlic is necessary for the development and fabrication of equipments and machinery.

A number of researchers have worked on the physical properties of garlic (Madamba et al., 1993, 1995, 1997; Pezutti and Crapsite 1997; Park et al., 1981; Bhatt et al., 1998; Sharma and Prasad 2002) but the literature on the development of garlic clove peeler is somewhat limited. Madamba et al., (1993) measured the length, width and thickness of garlic slices by using Vernier caliper. Song and Litch-field (1991) measured the length, width and thickness of garlic slices by using a computer imaging system while using a caliper to measure the third dimension.

Suwat Tansiri (1998) designed and developed the machine with $1200 \times 1900 \times 1900 \mathrm{~mm}$ (WLH) in dimensions consisting of three main units: processing from garlic bulbs to garlic cloves unit, sorting unit and peeling unit, using $3 \mathrm{hp}$ motor as power source. The peeling capacity of the machine is $33.19 \mathrm{~kg} / \mathrm{hr}$, $11.02 \%$ of completely peeled off garlic flesh, $11.25 \%$ of partly peeled off garlic fresh. Nagarajan (2006) developed a garlic peeling machine with a capacity $200 \mathrm{~kg} / \mathrm{h}$. The pressurized air pushed the garlic entering the peeling chamber from the big blower to the rotating blade. Since the blades were rotating, they hit the garlic towards the serrated wall of the peeling and it gets peeled. Mudgal and Chapawat (2008) tested the performance of an air-assisted garlic clove peeler. The height of the peeling chamber $(400 \mathrm{~mm})$, bed depth $(60$ $\mathrm{mm})$, air jet pressure $\left(10,15\right.$ and $\left.20 \mathrm{~kg} / \mathrm{cm}^{2}\right)$ and position of air jet $(60,80$ and $90 \mathrm{~mm})$ were taken for evaluation. The peeling efficiency was observed to be $97-98 \%$. 
Manjunatha et al., (2012) developed a power operated garlic peeler having cylinder concave mechanism. The cylinder covered with $10 \mathrm{~mm}$ thick rubber was fabricated and evaluation was done with cylinder speed (29, 36 and 42 rpm), cylinder concave clearance $(8,10$ and $12 \mathrm{~mm})$, moisture content $(23.1,27.7,33.4$ and $40.5 \%$ wet basis) and concave mechanisms. The peeling efficiency, yield of peeled garlic and unpeeled garlic, damage and peel separation were 86.6, 86.2, 4.7, 9.15 and $9.6 \%$ respectively at optimized parameters of cylinder speed of $36 \mathrm{rpm}$, cylinder concave clearance of $10 \mathrm{~mm}$, mild steel square $(8 \times 8$ screen). The machine had a throughput capacity of $27 \mathrm{~kg} / \mathrm{hr}$ and energy requirement of $1.15 \mathrm{kw}-\mathrm{h}$.

At present, the process of garlic peeling is done mostly manually which is a laborious operation. In order to overcome this and to accelerate the peeling operation, the study on the fabrication of small capacity garlic peeler was undertaken.

\section{Design considerations}

\section{Determination of moisture content}

The hot air oven method (AOAC 2000) was used to determine the moisture content of garlic cloves in which 5 gram sample was placed in dried petri-dish in a hot air oven. The operating temperature was $100 \pm 5^{\circ} \mathrm{C}$ until the constant weight was obtained. The fresh and bone dried sample was weighed with the help of electronic balance (Universal weighing machine) with a sensitivity of $0.001 \mathrm{~g}$ (1.200 kg capacity). The moisture content reported was on $\%$ wet basis. The moisture content was calculated using the following relationship:

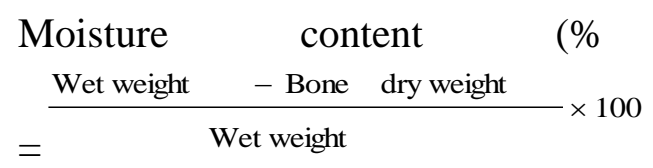

\section{Determination of engineering properties of garlic}

The present study represents the evaluation of various engineering properties of both peeled and unpeeled garlic cloves. The physical properties such as length, width and thickness were measured to estimate the geometric mean diameter and sphericity. For purpose, random sampling of garlic cloves was done in which 10 groups of samples consisting of 100 segments were selected to measure the three basic dimensions using a digital Vernier caliper with an accuracy of $0.01 \mathrm{~mm}$ (Madamba et al., 1993).Geometric mean diameter $\left(D_{p}\right)$ and sphericity $(\phi)$ were calculated using the formulas (Mohsenin, 1986).

$\mathrm{D}_{\mathrm{p}}=(\mathrm{abc})^{1 / 3,} \phi=(\mathrm{abc})^{1 / 3} / \mathrm{a}$

Frictional properties such as static coefficient of external friction and coefficient of internal friction were determined against two surfaces one wooden and other galvanized iron. These are helpful in design of bins, hopper and conveyers. A tilting table top set up consisting of wooden plank fixed on two adjustable screws was used. The formula used was

$\mu=\left(\mathrm{W}_{2}-\mathrm{W}_{1}\right) / \mathrm{W}$

Where, $\mathrm{W}_{1}$ - weight to cause sliding of box when empty, $\mathrm{W}_{2}$ - weight to cause sliding of box filled with sample material, W- weight of material in the box

Angle of repose is another physical property for describing the angle of hopper. The apparatus consists of conical hopper mounted above a circular base plate and a scale was attached to measure the height of heap. Angle of repose was determined using the following formula (Mohsenin, 1986).

$\phi_{\mathrm{r}}=\tan ^{-}\left(2 \mathrm{~h} / \mathrm{D}_{\mathrm{b}}\right)$ 
Where, h- height of heap $(\mathrm{cm}), \mathrm{D}_{\mathrm{b}}$ - Diameter of the base plate $(\mathrm{cm})$.

In order to determine the bulk density of cloves, a container or cylinder of known volume was used along with electronic balance and was calculated using the relationship:

$\mathrm{p}_{\mathrm{b}}=\mathrm{M} / \mathrm{V}$

Where $p_{\mathrm{b}}$ - bulk density, M- mass of the sample in grams, V- Volume of the same sample in cc.

The garlic segment volume $(\mathrm{V})$ and true density $\left(p_{p}\right)$ was determined using the liquid displacement method (Mohsenin, 1970; Sitkei, 1976; Singh and Goswami, 1996). Measuring cylinder was filled with toluene and known weight of cloves was poured.

The difference in the level of the toluene before and after pouring gave the volume of toluene displaced. The formula used for the calculation was:

$p_{\mathrm{p}}(\mathrm{g} / \mathrm{cc})=\mathrm{W} /\left(\mathrm{V}_{2^{-}}-\mathrm{V}_{1}\right)$

Where $\mathrm{W}$ - weight of sample in grams, $\mathrm{V}_{2}-$ Volume of cylinder after pouring the cloves (cc), $\mathrm{V}_{1}$ - Volume of cylinder before pouring the cloves(cc). The porosity $(\varepsilon)$ of cloves was calculated by using the following relationship which was expressed as in percentage from the bulk density and true density (Jha 1999).

$\varepsilon=\left(p_{p}-p_{b}\right) \times 100 / p_{p}$

\section{Design and fabrication of garlic peeler}

A small capacity power operated garlic peeler was fabricated consisting of hopper, wooden roller, cylindrical cover, blower and power transmission unit (Fig. 1 and 2). The peeler works on abrasion principle. The details of the fabricated parts are given in Table 4.

\section{Hopper}

Feeding hopper was made of MS sheet (22 gauge) with rectangular opening at the top and trapezoidal bottom. The feeding angle was designed taking into account the angle of repose of garlic.

The hopper was attached to the cylindrical unit to convey the feed under the gravitational force. The specifications of the hopper are as mentioned below.

Upper part $(\mathrm{L} \times \mathrm{W})=(30 \times 23) \mathrm{cm}$, Lower part $(\mathrm{L} \times \mathrm{W})=(17 \times 9) \mathrm{cm}$, Height of the hopper $=$ $16 \mathrm{~cm}$

Angle of repose is calculated using the formula, $\left(\phi_{\mathrm{r})}=\tan ^{-}(\mathrm{H} / \mathrm{B})\right.$

Where, $\mathrm{H}$ is the height of hopper and $\mathrm{B}$ is the effective base.

Here, $\mathrm{H}$ is $16 \mathrm{~cm}$ and $\mathrm{B}$ is $(30-17) \mathrm{cm}$. Using the formula, $\phi_{\mathrm{r}}=\tan ^{-}(16 / 13)=50.90$ degrees.

\section{Roller and cylindrical unit}

Roller and cylindrical unit consisted of wooden roller, outer cylindrical cover and an abrasive material. Wooden roller of $130 \mathrm{~mm}$ diameter and $210 \mathrm{~mm}$ length was prepared out of teak $\log$ of wood. The roller rotates over the MS rod (460 $\mathrm{mm}$ in length and $25.4 \mathrm{~mm}$ in diameter) driven by the power transmission unit. Nylon brushes of $40 \mathrm{~mm}$ length were fixed on the wooden roller with shoe nails.

Torque transmitted to the peeling chamber was calculated using the formula:

$\mathrm{hp}=2 \pi N T \div 60$

Where hp is the horsepower, $\mathrm{N}$ is the rpm of roller. 
Maximum and minimum torque Bending moment of the shaft transmitted to the roller was calculated

Case 1- For maximum RPM $=500$

$\mathrm{M}_{\mathrm{b}}=\frac{E \times I}{r}$

$2 \pi N T \div 60$

$\mathrm{hp}=$

$1 \mathrm{hp}$ motor was used for the rotation of roller and $1 \mathrm{hp}=746$ watts

So $\mathrm{T}=\frac{60 \times 746}{2 \pi \times 500}=14.247 \mathrm{~N}-\mathrm{m}$

Where $\mathrm{E}$ is the moduluds of elasticity in $\mathrm{N} / \mathrm{mm}^{2}, \mathrm{I}$ is the moment of inertia in $\mathrm{mm}^{4}$ and $r$ is the radius of MS $\operatorname{rod}\left(E=200 N / m^{2}\right.$ for mild steel).

$\mathrm{M}_{\mathrm{b}}=\frac{2 \times 20431.71}{12.7 \times 10000}=0.321 \mathrm{~N}-\mathrm{mm}$

The wooden roller was covered with cylindrical unit divided into two hemispherical sections. The length, width and height of the hemispherical section was designed as 280 $\mathrm{mm}, 235 \mathrm{~mm}$ and $175 \mathrm{~mm}$ respectively. The cylindrical unit was fabricated out of MS sheet (22 gauge). From inside, the cylindrical cover was lined with nylon abrasive mat which was fixed with $3 / 16$ zisti nut and bolt.

Shearing stress on the rod

$\tau=\frac{16 \times T \times 1000}{\pi d^{3}}$

Where $\mathrm{T}$ is the torque in $\mathrm{N}-\mathrm{m}$ and $\mathrm{d}$ is the diameter of the rod in $\mathrm{mm}$

Maximum shearing stress, $\tau$

The clearance between the abrasive material and roller was adjustable and was adjusted to $1 / 2$ inch. The whole unit was installed below the feed hopper and beneath was supported by the main frame of the machine. The upper hemispherical part of the cylinder is movable with the help of jointer in order to facilitte the cleaning process.

Minimum shearing stress, $=\frac{16 \times 14.247 \times 1000}{\pi \times(25.4)^{3}}=4.427 \mathrm{~N} / \mathrm{mm}^{2}$

Moment of inertia of the $\operatorname{rod}\left(\mathrm{mm}^{4}\right)$

$\mathrm{I}=\frac{\pi \times d^{4}}{64}$

Where $\mathrm{d}$ is the diameter of MS rod in $\mathrm{mm}$.

Therefore, $\mathrm{I}=\frac{\frac{\pi \times(25.4)^{4}}{64}}{64}=20431.71 \mathrm{~mm}^{4}$

Driving mechanism

The roller was driven by $\mathrm{V}$ - belt (B-30) drive to transmit the power. Two pulleys (A section with $650 \mathrm{~mm}$ diameter), one roller pulley and other motor pulley were used to transmit the power from one point to other with the help of belt.

No gear reduction was done at the driver and driven pulleys. Two bearings of P-204 were provided at the ends of the shaft for smooth and frictionless running of the shaft. 


\section{Power mechanism}

A single phase DC motor was used as a power source with the following specifications. A variable speed control panel was attached to vary thr RPM of the roller. Energy consumption was measured from the single phase energy meter attached to the machine.

\section{Cleaning and discharge section}

Peel separation and discharge of peeled and unpeeled mixture takes place at the bottom side of the cylinder. Peel separation was done with $1 / 4 \mathrm{hp}$ single phase blower and was driven with $1 \mathrm{hp}$ motor. The separation of the peeled and unpeeled cloves was done manually and was fed again into hopper for peeling.

\section{Main frame}

The main frame was fabricated out of angle iron of $1 / 4$ inch $\times 6 \mathrm{~mm}$ for mounting the different parts such as roller, cylinder unit, cleaning, discharge section and transmission unit. The length, width and height of the frame were $630 \mathrm{~mm} \times 470 \mathrm{~mm} \times 960 \mathrm{~mm}$ respectively.

Experimental evaluation of small scale garlic peeler

\section{Material}

To accomplish the selected objectives, the experiments were conducted in various laboratories of the Department of Processing and Food Engineering, Punjab Agricultural University, Ludhiana. Fresh garlic was procured from the local market and was stored at ambient air conditions.

\section{Pretreatment}

Garlic samples were pretreated with hot water and hot air. Hot water treatment was given by dipping the cloves in water heated at $90^{\circ} \mathrm{C}$ for 2 minutes. Hot air pretreatment was given by heating the samples in convective tray drier at $60^{\circ} \mathrm{C}$ for an hour with air velocity of $1 \mathrm{~m} / \mathrm{s}$ (Manjunatha et al., 2012).

\section{Performance evaluation of garlic peeler}

The machine was tested for its peeling efficiency at different levels of roller speed and different moisture contents of pretreated and control samples. For testing the effectiveness, $1 / 2 \mathrm{~kg}$ of batch sample was fed into the hopper and time required for each peeling was noted. Corresponding weight of peeled, unpeeled, damaged and peel was noted done by weighing on electronic balance. Percentages of various fractions were obtained by using the following formulae.

Percentage of peeled cloves $=\frac{W_{p}}{W_{p}+W_{u}} \times 100$

Where $\mathrm{Wp}$ - weigth of peeled cloves, Wu weigth of unpeeled cloves

Percentage of unpeeled cloves =

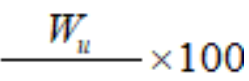

Where $\mathrm{Wp}$ - weigth of peeled cloves, $\mathrm{Wu}-$ weigth of unpeeled cloves

Percentage peeled clove recovery $=\frac{W_{p}}{W} \times 100$

Where Wp - weight of peeled cloves, W weight of garlic cloves

\section{Machine peeling capacity}

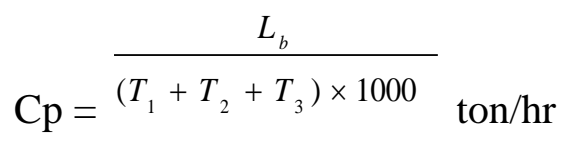


$\mathrm{T}_{1}=$ loading time in minutes, $\mathrm{T}_{2}=$ peeling residence time in minutes, $\mathrm{T}_{3}=$ unloading time in minutes, $\mathrm{L}_{\mathrm{b}}=$ batch load $(\mathrm{kg})$.

\section{Statistical analysis}

The analysis of performance evaluation of machine and effect of pretreatments on the peeling efficiency and peeled clove recovery was done using two way ANOVA technique (SAS software) and GraphPad PRISM Version 6 software, Inc. USA. The Results of analysis were used to evaluate the significant difference among the various parameters at $\mathrm{p}$ $<0.05$.

\section{Results and Discussion}

\section{Engineering properties}

The values of average length, width and thickness were determined for both peeled and unpeeled cloves. From these, the average values of geometric mean diameter were found to be $11.820 \mathrm{~mm}$ and $11.048 \mathrm{~mm}$ respectively for unpeeled and peeled cloves. Forb the peeled cloves, the maximum average length, width and thickness was found to be $22.579 \mathrm{~mm}, 9.58 \mathrm{~mm}, 7.815 \mathrm{~mm}$ (Table 1). Similar results for the length, width, thickness and geometric mean diameter were reported by Haciseferogullari et al., (2005). The values reported were $14.46 \pm 0.437,9.25 \pm 0.240$ and $15.15 \pm 0.285 \mathrm{~mm}$ respectively for the garlic (whole and segments) at $66.32 \%$ moisture content on dry basis.

The sphericity values for the unpeeled and peeled cloves were found to be 0.494 and 0.526 . Higher the sphericity values, the shape approaches more towards a sphere. So, the peeled cloves exhibit sphere like character. Masoumi et al., (2006) reported that sphericity values lied in the range of $0.58-0.91$ for white and $0.57-0.87$ for pink garlic cloves at $42.4 \%$ moisture content on wet basis.
The average values of static coefficient of friction for unpeeled and peeled cloves were calculated as 0.366 and 0.772 respectively for wooden and GI surface. For the peeled cloves, the average values for the wooden and GI surface was found to be 0.664 and 0.812 respectively (Table 2). The values for the peeled cloves were reported higher than that of unpeeled cloves because of reduction in the surface smoothness of peeled cloves. The maximum values of static coefficient were reported of peeled cloves for GI surface with value of 0.812 .

The efforts made by other researchers showed that the static coefficient of friction values were near to values reported in the present study. The surfaces used were galvanized sheet, iron sheet and plywood and the corresponding values for the garlic segments were $0.416 \pm 0.018,0.472 \pm 0.023$ and $0.541 \pm$ 0.028 respectively (Haciseferogullari et al., 2005).

The peeled cloves have less angle of repose because of lower moisture content and the values for unpeeled cloves was 39.881 degrees and for the peeled cloves was 25.529 degrees. Similar, trend was shown by Haciseferogullari et al., (2005) for the angle of repose of segments which increased from 25.5 to 37.5 degrees with increase in moisture content from 23.1 to $40.5 \%$ wet basis. It could be attributed to the increase in cohesiveness between the garlic segments.

The bulk density determined using the standard method was found to be $0.471 \mathrm{~g} / \mathrm{cc}$ and $0.556 \mathrm{~g} / \mathrm{cc}$ for the unpeeled and peeled cloves respectively (Table 3). Haciseferogullari et al., (2005) reported the bulk density of garlic segments as $0.479 \mathrm{~g} / \mathrm{cc}$. True density was calculated using toluene displacement method. The average values reported were $1.077 \mathrm{~g} / \mathrm{cc}$ and $1.169 \mathrm{~g} / \mathrm{cc}$ for the unpeeled and peeled cloves respectively. 
Fig.1 Schematic view of developed peeler

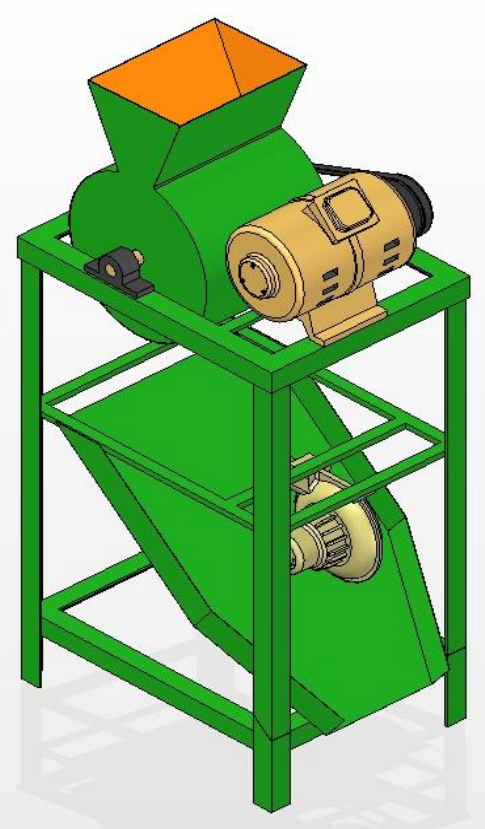

Fig.2 Actual view of developed peeler

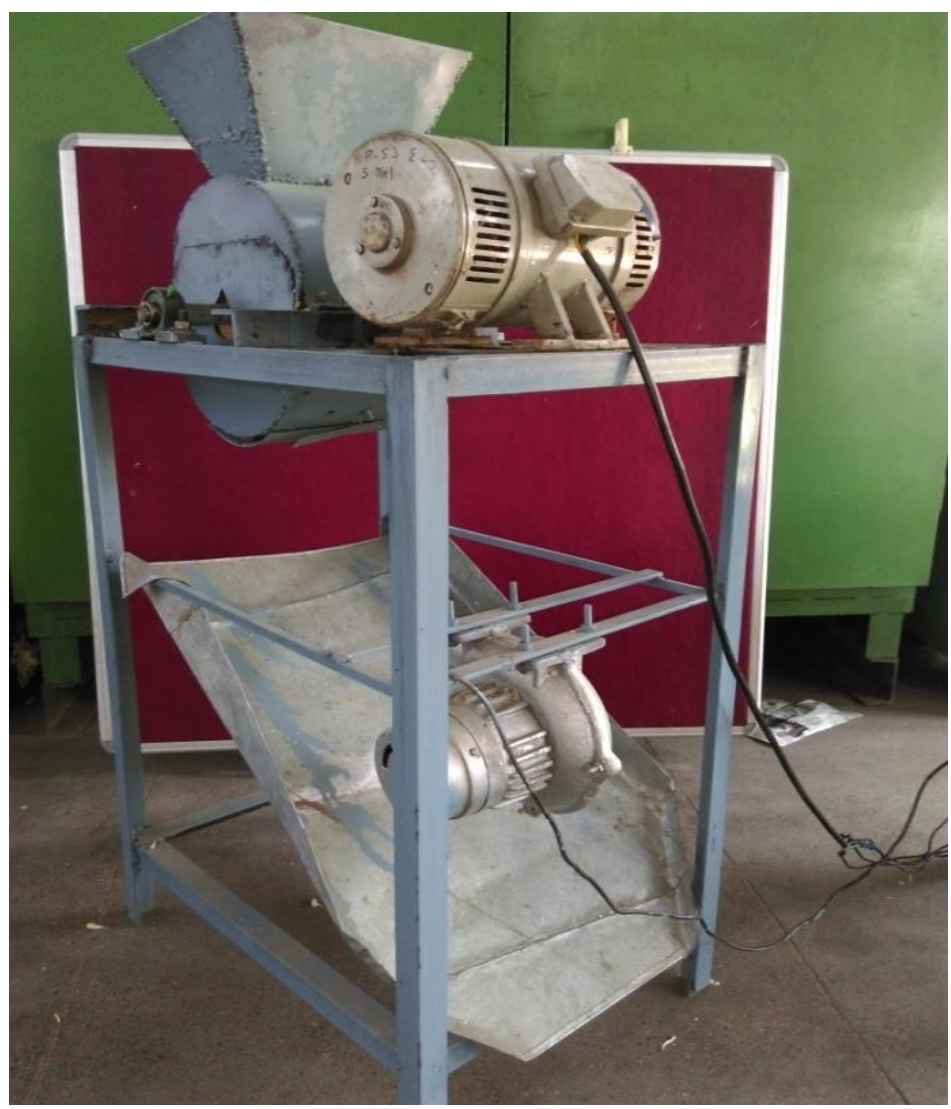


Fig.3 Peeling efficiency as affected by roller speed and pretreatment

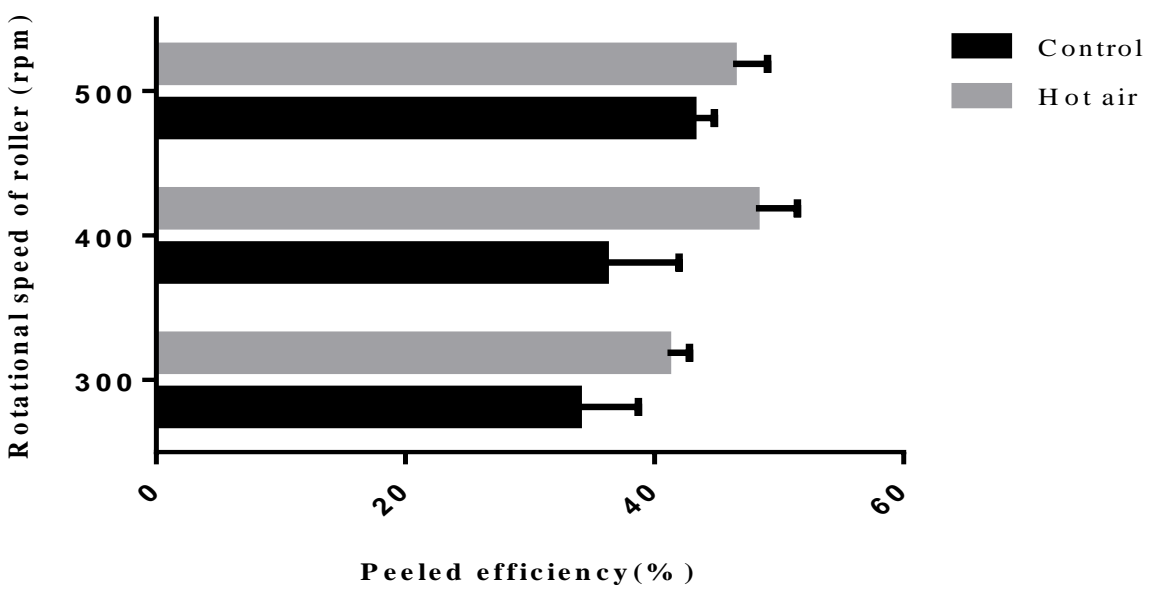

Fig.4 Effect of rotational speed and pretreatment on peeled clove recovery

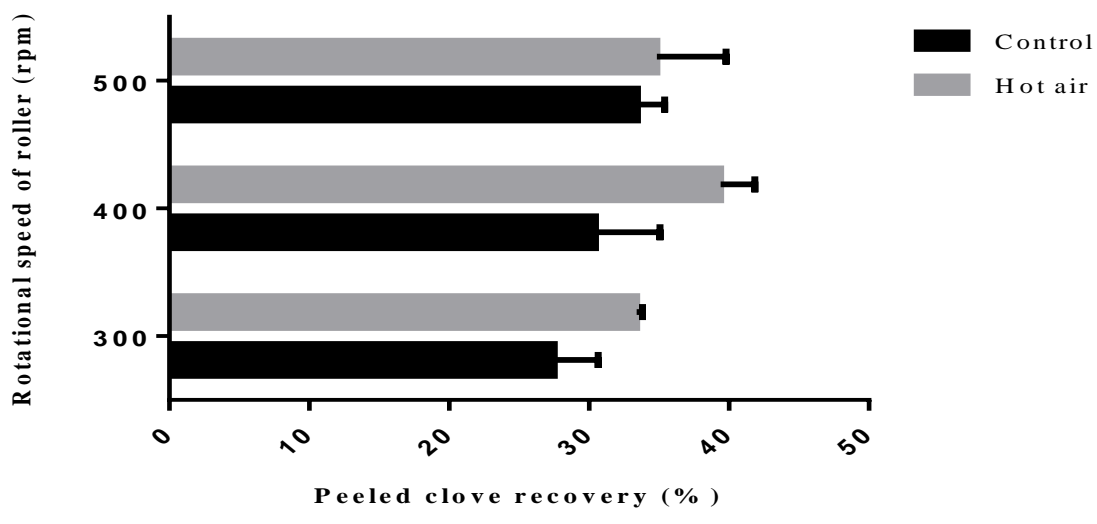

Fig.5 Control sample after peeling in the peeler

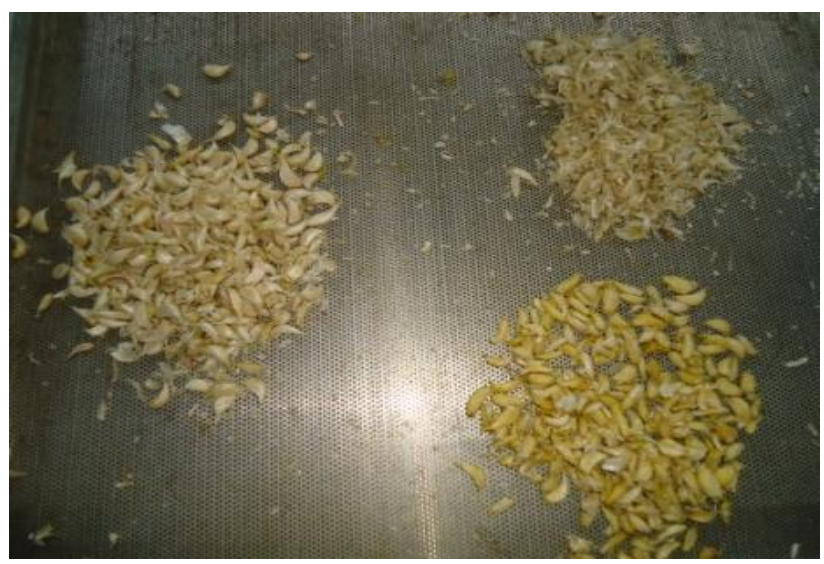


Fig.6 Hot air pretreated sample after peeling

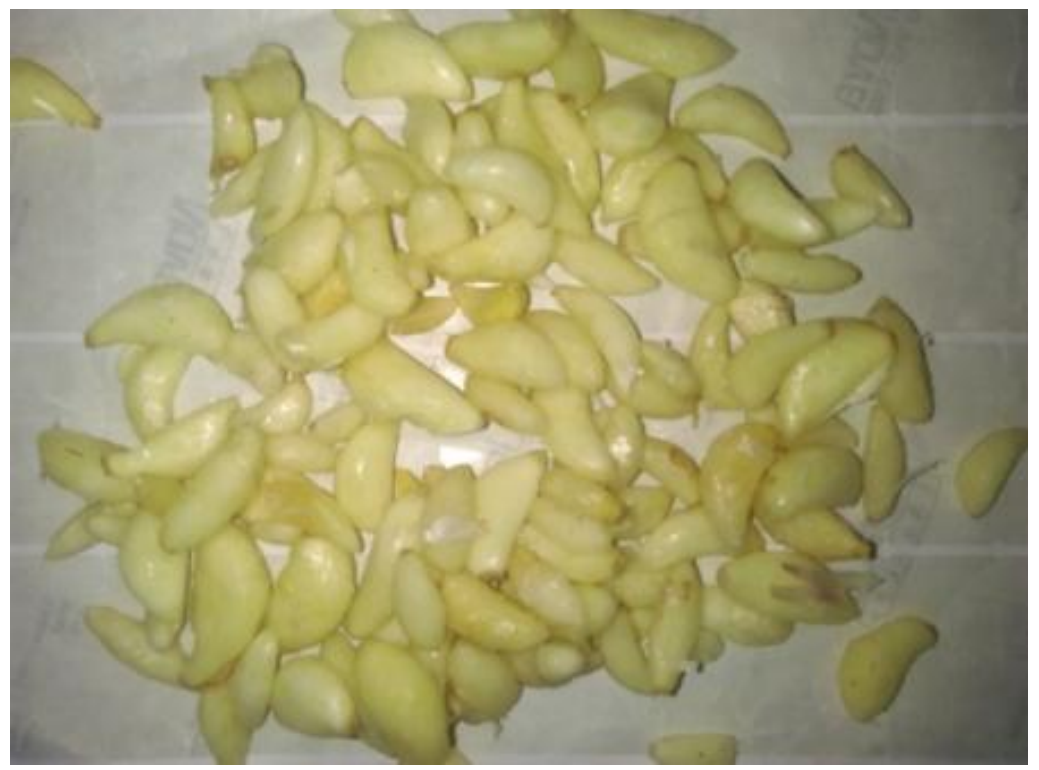

Table 1 Average values $( \pm$ SD) of dimensions, geometric mean diameter and sphericity of unpeeled and peeled cloves.

Treatment

Property

Unpeeled Peeled

\begin{tabular}{lcc}
\hline Average length, a $(\mathrm{mm})$ & $23.882(4.747)$ & $21.002(3.087)$ \\
\hline Average width, b (mm) & $9.423(1.414)$ & $9.053(1.622)$ \\
\hline Average thickness, c (mm) & $7.331(0.987)$ & $1.168(1.285)$ \\
& & $11.048(1.552)$ \\
\hline Geometric mean diameter, & $11.820(1.207)$ & $0.526(0.189)$ \\
& & \\
\hline Sp (mm) & $0.494(0.061)$ & \\
& & \\
\end{tabular}


Table 2 Average values of coefficient of friction for wooden surface and GI sheet.

$\begin{array}{lll}\text { Property } & \text { Type of surface } & \text { Garlic samples }\end{array}$

Coefficient of external

Peeled $\left(\mu_{\mathrm{e}}\right)$

Unpeeled $\left(\mu_{\mathrm{e}}\right)$

friction

Wooden $\quad 0.664 \quad 0.366$

GI sheet

0.812

0.772

Coefficient of internal friction

0.570

0.826

Table 3 Average values $( \pm$ SD) of other engineering properties of unpeeled and peeled cloves.

Treatment

Unpeeled

Peeled

Property

\begin{tabular}{lcc}
\hline Bulk density $(\mathrm{g} / \mathrm{cc})$ & $0.471(0.007)$ & $0.556(0.019)$ \\
\hline True density $(\mathrm{g} / \mathrm{cc})$ & $1.077(0.067)$ & $1.169(0.038)$ \\
& & \\
\hline Porosity $(\%)$ & $56.179(3.027)$ & $52.413(1.899)$
\end{tabular}


Table.4 Components of the machine

\begin{tabular}{|c|c|}
\hline Components & Specifications \\
\hline $\begin{array}{l}\text { Hopper } \\
\text { Material } \\
\text { Dimensiosns of upper part }(L \times W) \\
\text { Dimensions of lower part }(L \times W) \\
\text { Height from the base of hopper }\end{array}$ & $\begin{array}{l}\text { MS Sheet }(22 \text { gauge }) \\
30 \times 23(\mathrm{~cm}) \\
17 \times 9(\mathrm{~cm}) \\
16 \mathrm{~cm}\end{array}$ \\
\hline $\begin{array}{l}\text { Roller } \\
\text { Material } \\
\text { Diameter } \\
\text { Length }\end{array}$ & $\begin{array}{l}\text { Wood } \\
130 \mathrm{~mm} \\
210 \mathrm{~mm}\end{array}$ \\
\hline $\begin{array}{l}\text { Shaft } \\
\text { Material } \\
\text { Length } \\
\text { Diamter }\end{array}$ & $\begin{array}{l}\text { Mild steel } \\
460 \mathrm{~mm} \\
254 \mathrm{~mm}\end{array}$ \\
\hline $\begin{array}{l}\text { Nylon brushes } \\
\text { Number of brushes } \\
\text { Length of each brush }\end{array}$ & $\begin{array}{l}4 \\
40 \mathrm{~mm}\end{array}$ \\
\hline $\begin{array}{l}\text { Cylinderical Cover with two hemispherical } \\
\text { halves } \\
\text { Material } \\
\text { Length } \\
\text { Width } \\
\text { Height }\end{array}$ & $\begin{array}{l}\text { MS flat sheet (22 guage) } \\
280 \mathrm{~mm} \\
235 \mathrm{~mm} \\
175 \mathrm{~mm}\end{array}$ \\
\hline Belt & B- $30 \mathrm{~V}$ belt \\
\hline $\begin{array}{l}\text { Pulleys for power transmission } \\
\text { Motor and roller pulley } \\
\text { Type } \\
\text { Diameter }\end{array}$ & $\begin{array}{l}\text { A type, } 2 \text { in number } \\
650 \mathrm{~mm}\end{array}$ \\
\hline $\begin{array}{l}\text { Bearings } \\
\text { Material } \\
\text { Type } \\
\text { Number } \\
\end{array}$ & $\begin{array}{l}\text { Gun metal } \\
\text { P-204 } \\
2\end{array}$ \\
\hline $\begin{array}{l}\text { Power Mechanism } \\
\text { Motor } \\
\text { Hp } \\
\text { Volts } \\
\text { AMP's } \\
\text { Maximum RPM } \\
\text { Duty } \\
\text { Winding }\end{array}$ & $\begin{array}{l}\text { Single phase, DC } \\
1 \\
220 \\
4 \\
1500 \\
\text { Cont } \\
\text { Shunt }\end{array}$ \\
\hline $\begin{array}{l}\text { Cleaning unit } \\
\text { Blower Power }\end{array}$ & $1 / 4 \mathrm{hp}$ single phase driven by $1 \mathrm{hp}$ motor \\
\hline $\begin{array}{l}\text { Main frame } \\
\text { Material } \\
\text { Length } \\
\text { Width } \\
\text { Height }\end{array}$ & $\begin{array}{l}\text { Angle iron }(1 / 4 \text { inches } \times 6 \mathrm{~mm}) \\
630 \mathrm{~mm} \\
470 \mathrm{~mm} \\
960 \mathrm{~mm}\end{array}$ \\
\hline
\end{tabular}




\section{Table.5 Economic analysis}

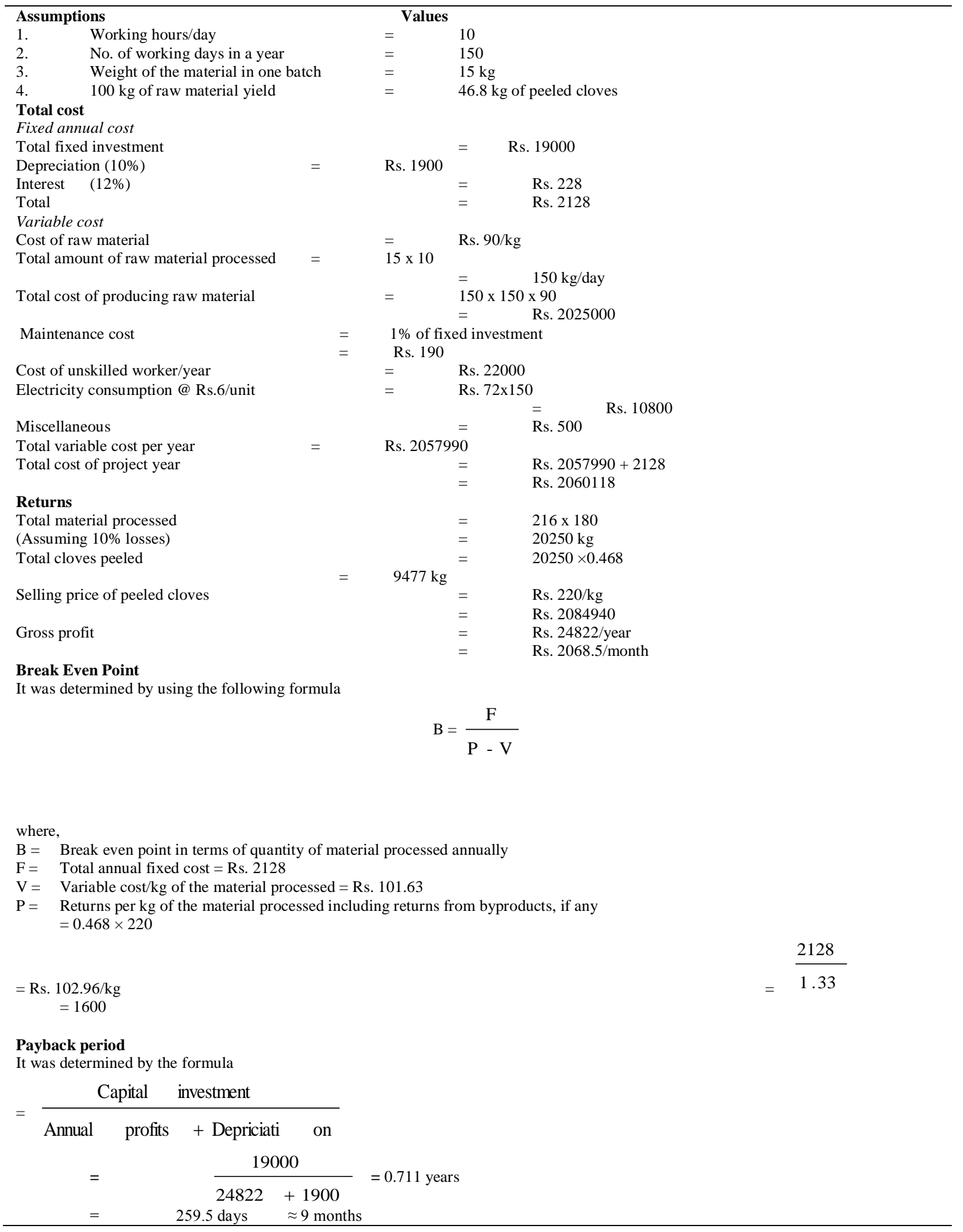


Int.J.Curr.Microbiol.App.Sci (2019) 8(8): 619-634

Table 6 Analysis of variance (ANOVA) for peeling efficiency

\begin{tabular}{lrrrrr}
\hline Source & DF & Type III SS & Mean Square & F Value & Pr > F \\
Pretrtmnt & 1 & 2108.777216 & 2108.777216 & 121.80 & $<.0001$ \\
Rolr_Speed & 2 & 102.740622 & 51.370311 & 2.97 & 0.0706 \\
Pretrtmnt*Rolr_Speed & 2 & 259.516368 & 129.758184 & 7.49 & 0.0030 \\
\hline
\end{tabular}

Table 7 Analysis of variance for peeled clove recovery

\begin{tabular}{lrrrrr}
\hline Source & DF & Type III SS & Mean Square & F Value & Pr > F \\
Pretrtmnt & 1 & 608.2202133 & 608.2202133 & 38.82 & $<.0001$ \\
Rolr_Speed & 2 & 429.7433600 & 214.8716800 & 13.71 & 0.0001 \\
Pretrtmnt*Rolr_Speed & 2 & 354.9316267 & 177.4658133 & 11.33 & 0.0003 \\
\hline
\end{tabular}

Masoumi et al., (2006) studied the relationship between porosity and moisture content of white and pink garlic cloves. The porosity decreased from 59 to $45 \%$ and 57 to $39 \%$ for white and pink garlic cloves when the moisture content increased from 34.9 to $56.7 \%$ wet basis. For the unpeeled cloves, the value of porosity was $56.17 \%$ and for the peeled cloves was $52.43 \%$.

\section{Machine peeling capacity}

Machine peeling capacity was calculated using the formula of Ghobashy et al., (2012).

$\mathrm{Cp}=\frac{L_{b}}{\left(T_{1}+T_{2}+T_{3}\right) \times 1000}$ ton $/ \mathrm{h}$

Here, $\mathrm{T}_{1}=0.5 \mathrm{~min}, \mathrm{~T}_{2}=1 \mathrm{~min}, \mathrm{~T}_{3}=0.5 \mathrm{~min}$ and $\mathrm{L}_{\mathrm{b}}=0.5 \mathrm{~kg}$, so $\mathrm{Cp}=0.015$ ton $/ \mathrm{h}$.

\section{Calculation of peeling efficiency and peeled clove recovery}

\section{Effect of pretreatment on peeling efficiency}

Two types of garlic samples, control and hot air blanched were evaluated for peeling efficiency at different levels of 300, 400 and 500 roller speeds. The corresponding moisture contents of control and hot air pretreated samples were observed to be 62.63 $\%$ and $59.11 \%$ respectively on the wet basis. It was observed from the Fig. 3 that for the same roller speed, the average peeeling efficiency was reported to be higher for hot air pretreated samples than the control ones.

The maximum peeling efficiency was observed to be $48.14 \%$ for hot air pretreated samples at 400 roller speed and minimum to be $33.89 \%$ at 300 roller speeds for control samples (Fig. 3). Similar results were reported by Manjunatha et al., (2012) for the average peeling efficiencies at the corresponding moisture contents of 23.1, 27.7, 33.4 and $40.5 \%$. The efficiencies reported were 79.71 , $81.16,78.27$ and $68.73 \%$.

The values of peeling efficiency increased with decrease in moisture content due to the loosening of garlic skin on tray drying. Moreover, loosening of skin reduced the damage and mashing of cloves. Statistically, it was found that pre-treatment was highly significant on the peeling efficiency. 
Effect of rotational speed on peeling efficiency

Rotational speed of the roller has non significant effect on the peeling efficiency of garlic. It was observed from the Fig. 4 that the mean value of peeling efficiency increases with increase in rotational speed at constant batch load of $1 / 2 \mathrm{~kg}$ and constant peeling residence time of one minute. The minimum peeling efficiency was observed to be $33.89 \%$ at $300 \mathrm{rpm}$ and maximum was $43.07 \%$ at 500 roller speed for control samples. For hot air pretreated samples, the minimum and maximum peeling efficiencies were $41.05 \%$ and $48.14 \%$ at 300 and 400 roller speeds respectively. Taking into account the combined factor, the combination of pretreatment and roller speed was significant.

Similar results were reported by Manjunatha et al., (2012), that the peeling efficiency was higher at $36 \mathrm{rpm}$ as compared to 42 and 29 rpm at $27.7 \%$ moisture content at all the three levels of cylinder concave clearance. It was due to the reason that at the lower rpms more damage occurs because of prolonged abrasion and impact of the roller. Moreover, higher $\mathrm{rpm}$ results in increase in efficiency but at the same time it causes physical rupture and mashing of cloves.

\section{Effect of pretreatment on peeled clove recovery}

Comparing the two samples- control and hot air, the peeled clove recovery for hot air pretreated samples was higher at one constant roller speed. Similar results were reported by Manjunatha et al., (2012) that average peeled garlic cloves were found to be 78.49, 80.09, 76.89 and $65.76 \%$ to the corresponding moisture contents of 23.1, 27.7, 33.4 and $40.5 \%$ respectively. Statistically, pretreatment was found to be highly significant on the peeled clove recovery $(\mathrm{p}<0.05)$ (Table $7)$. The peeling experiment was also run for hot water blanched sample. It was found that the samples were in good condition but peeling in machine was not successful as the outer skin got adhered to the clove surface and abrasion principle did not work.

\section{Effect of rotational speed on peeled clove recovery}

The peeled clove recovery also exhibited the same trend as that of peeling efficiency. With an increase in the rotational speed of the roller, the peeled clove recovery also increased for control samples. For hot air pretreated samples, the trend observed was discontinuous. The effect of roller speed was found to be highly significant. With an increase from $300 \mathrm{rpm}$ to $400 \mathrm{rpm}$ in Fig. 4, the peeled clove recovery increased but with further increase from 400 to $500 \mathrm{rpm}$, the recovery decreased. It was due to the reason that increased rpm causes more abrasion and cloves get crushed as compared to at lower rpm's. The maximum peeled clove recovery calculated was $39.40 \%$ for hot air pretreated sample at $400 \mathrm{rpm}$ and minimum of $27.50 \%$ at $300 \mathrm{rpm}$ for control samples. The combination of pre-treatment and roller speed was also significant for the peeled clove recovery (Fig. 5 and 6).

\section{Economic feasibility of developed garlic peeler}

Economic analysis of garlic clove peeler was done to test the feasibility of machine taking into account the total cost which includes fixed cost and variable cost, returns, breakeven point and payback period (Table 5).

\section{References}

Ahmad, J. I. (1996). Garlic-apanacea for Health and Good Taste. Journal of Nutrition and Food Science, 96(1), 32-35.

Anonymous (2000) AOAC- Official methods of analysis, Association of official analytical chemists. Washington DC, USA. 
Bhatt, R.P., Biswas, V.R. and Kumar, N.A. (1998). Note physico- chemical characteristics of some Geno- types of garlic. Journal of Vegetation Science, 25(1), 95-96.

Ghobashy, E.I., Bahnasawy Adel, H., Smair, A. Ali. and Afifiy, M. T. (2012). Development and evaluation of an onion peeling machine. Misr Journal of Agricultural Engineering, 27(1), 663-682.

Haciseferogullari, H., Ozcan, M., Demir, F. and Calisir, S. (2005). Some nutritional and technological properties of garlic (Allium sativum L.). Journal of Food Engineering, 68,463-69.

Jha, N.S. (1999). Physical and Hygroscopic Properties of Makhana. Journal of Agricultural Engineering and Research, 72, 145-50.

Madamba, P.S., Driscoll, R.H., Buckle, K.A. (1993). Moisture content determination of garlic by convection oven method. ASEAN Food, 8, 81-83.

Manjunatha, M., Samuel, D.V.K., Rahul, K. and Anurag (2012). Development and performance evaluation of a garlic peeler. Journal of Food Science and Technology (DOI 10.1007/s13197-012-0879-5).

Masoumi, A.A., Rajabipour, A., Tabil, L. and Akram, A. A. (2006). Physical Attributes of garlic (Allium sativum L.) Journal of Agricultural Science and Technology, 8, 15-23.

Mohsenin, N. N. (1970). Physical Properties of Plant and Animal material. New York: Gordon and Breach, Sc. Pub. Pp, 51-87. 889.

Mohsenin, N.N. (1986). Physical Properties of Plant and Animal Materials, 2nd edition. Gordon and Breach Science Publishers 14.

Mudgal, V. D. and Champawat, P.S. (2008). Influence of Operating Parameters on Performance of Air -assisted Garlic Clove
Peeler. Journal of Agricultural Engineering, 45(3).

Mudgal, V.D., Bordia, J.S., Jain, N. K. and Seth, P. (1998). Research digest - A Compilation of Research Achievements (1977-1997) of AICRP on Post-Harvest Technology, College of Technology and Agricultural Engineering, Udaipur.

Nagarajan, M. (2006). Lemon Cutting Machine and Garlic Peeling Machine. National innovation Foundation. Online source culled from (http://www.nif.org.in/lemon garlic_machine.) (accessed on 12April, 2014).

Park, M. H., Koh, H. Y., Shin, D. H. and Suh, K.B. (1981). Study on the Long Term Storage of Garlic Bulbs. Journal of Korean Agricultural Chemical Society, 24(4), 21823.

Pezutti, A. and Crapsite, G.H. (1997). Sorptional equilibrium and drying characteristics of garlic. Journal of Food Engineering, 31, 113-23.

Sharma, G.P. and Prasad, S. (2002). Dielectric Properties of Garlic (Allium sativum L.) at $2450 \mathrm{MHz}$ as Function of Temperature and Moisture Content. Journal of Food Engineering, 52,343-348.

Singh, K. K. and Goswami, T.K. (1996). Physical properties of cumin seed. Journal of Agricultural Engineering and Research, 64, 93-98.

S1tkei, G. (1976). Mechanics of agricultural materials, Department of Woodworking Machines, University of Forestry and Wood Science, Sopron, Hungary, p. 487.

Song, H. and Litchfield, J.B. (1991). Predicting Method of Terminal Velocity for Grains. Transactions ASAE, 34(1), 225-30.

Suwat, T. (1998). Design and development of garlic processing machine. M.Tech thesis, Kasetsart University, Bangkok, Thailand.

\section{How to cite this article:}

Maninder Kaur, Preetinder Kaur and Mahesh Kumar. 2019. Development and Fabrication of Small Capacity Garlic Peeler. Int.J.Curr.Microbiol.App.Sci. 8(08): 619-634. doi: https://doi.org/10.20546/ijcmas.2019.808.073 